\title{
Biomolecule Damage (DNA and Lipid) is Elevated in Patients with Type 1 Diabetes with and without Diabetic Complications
}

\author{
Mary P.A. Hannon-Fletcher ${ }^{1, *}$, Maurice J. O’Kane ${ }^{2}$, Ken W. Moles ${ }^{2}$, Colin Weatherup ${ }^{1}$ and \\ Yvonne A. Barnett ${ }^{3}$
}

${ }^{1}$ School of Health Sciences, University of Ulster, Shore Road, Newtownabbey, County Antrim, BT37 OQB, Northern Ireland

${ }^{2}$ Altnagelvin Area Hospital, Glenshane Road, Londonderry, BT47 1SB, Northern Ireland

${ }^{3}$ Science and Technology, Nottingham Trent University, Clifton lane, Nottingham, NG11 8NS, UK

\begin{abstract}
There is strong evidence that oxidative stress is involved in the aetiology and pathogenesis of diabetes and its complications. Increased production of reactive oxygen species in vivo can lead to cellular biomolecule damage, such as lipid peroxidation and DNA damage.

The aim of this study was to determine the extent of this damage by measuring in vivo antioxidant status, levels of lipid peroxidation, and levels of neutrophil DNA damage in 50 participants with type 1 diabetes and 50 age- and sex-matched, healthy controls.

Gylcaemic control (\%HbA1c) was relatively good with a group mean of $7.71 \%$ which increased to $8.12 \%$ in those with complications. Compared to the control group there were significantly elevated levels of neutrophil DNA damage (\% tail DNA, $p<0.0001)$ and plasma MDA levels $(p<0.05)$ in the Type 1 group as a whole, this significance rose to $p<0.01$ in those with complications. There were significant alterations in markers of antioxidant status including, reduced levels of superoxide dismutase $(p<0.0001)$, uric acid $(p<0.05)$ and Vitamin $C(p<0.05)$ and elevated levels of catalase $(p<0.001)$

These results indicate that even with acceptable glycaemic control significant oxidative damage still occurs and this damage increases, in some indices, with the onset of complications.
\end{abstract}

Keywords: DNA damage, Type 1 Diabetes, Lipid damage, Glycaemic control, oxidative stress.

\section{INTRODUCTION}

There is longstanding evidence linking free radicals and oxidative stress to the aetiology and pathogenesis of Type 1 diabetes (Type 1) and the resulting cardiovascular complications [1-3]. In vivo antioxidant changes have been observed in individuals with Type 1 with [4] and without complications [4, 5]. It has been suggested that a source of the damaging oxidative species may be hyperactive macrophages and/or neutrophils $[6,7]$.

Under conditions of oxidative stress damage to cellular biomolecules (lipids, proteins, carbohydrates and DNA) can occur. Lipid peroxidation, a type of oxidative degeneration of polyunsaturated lipids, has been shown to be involved in the pathogenesis of diabetes. [8, 9] $\mathrm{A}$ broad range of oxidation products have been described including 4-hydroxy-2-nonenal (4$\mathrm{HNE}$ ) and malondialdehyde (MDA). Oxidation of lipids in plasma lipoproteins and in cellular membranes is associated with the development of vascular disease in diabetes [10]. Oxidative stress and poor metabolic

*Address correspondence to this author at the School of Health Sciences, University of Ulster, Shore Road, Newtownabbey, County Antrim, BT37 0QB, Northern Ireland; Tel +44 (0) 28 90366914; E-mail: mp.hannon@ulster.ac.uk control have been shown to enhance lipid peroxidation in Type 1, especially in those patients with complications [4]. A number of lipid peroxidation products mainly, MDA and 4-hydroxy-2-nonenal are known to interact with DNA [11, 12]. This oxidative damage to DNA can lead to cytotoxicity, genotoxicity and carcinogenicity [13] and may contribute to genetic diseases and cancer in humans. Oxidative damage to DNA has been determined by several authors using various techniques [14-18]. They have reported increases [14-16] and no changes [17, 18] in levels of DNA damage in Type 1 patients.

Under normal conditions antioxidant defences act to minimise the production of harmful levels of oxidants. Such defences include; lipid (vitamin A and E) and water soluble (vitamin C) antioxidants; and antioxidant enzymes, superoxide dismutase (SOD), catalase (CAT), glutathione peroxidase (GPx) and caeruloplasmin. However, diabetes has been reported to represent a state of oxidative stress, $[1,4]$ either as a result of overproduction of precursors of ROS and/or decreased efficiency of inhibitory and scavenging systems.

In this paper we report basal levels of DNA damage, levels of lipid peroxidation and in vivo antioxidant status 
in a group of 50 well-controlled individuals with Type 1 (with and without overt complications) compared to 50 age- and sex-matched, healthy control participants.

\section{MATERIALS AND METHODS}

\section{Participants}

50-Individuals with Type 1 (mean age $36.4 \pm 1.96$ years; 30 males and 20 females; 8 smokers), were recruited from the diabetic clinic at Altnagelvin Hospital, Londonderry, Northern Ireland. The Helsinki Declaration of 1975 (revised 1983) was followed and ethical approval for this study was obtained from the University of Ulster Ethical Committee and from the Ethical Committee at Altnagelvin Hospital. All participants gave informed consent before commencing on the study. Type 1 participants were assessed for the presence of a number of diabetic complications (retinopathy, nephropathy, neuropathy, and macrovascular disease) and evidence of microalbuminuria and ketosis was noted. In addition we obtained information on duration of diabetes, smoking history, vitamin supplement usage and other drug intake for each participant. The control group consisted of 50 healthy individuals recruited from the University of Ulster (mean age $37.6 \pm 1.49$ years; 22 females and 28 males, none of whom were smokers or taking prescribed/non-prescribed medication, nor did they have a family history of diabetes).

\section{Collection and Processing of Blood Samples}

$25 \mathrm{ml}$ of peripheral blood was collected from each non-fasting study participant before noon. $2 \times 5 \mathrm{ml}$ was collected into lithium heparin-coated vacutainers ${ }^{\circledR}$ (Becton-Dickinson, UK) and stored on ice, for subsequent processing to determine antioxidant status. An additional $5 \mathrm{ml}$ was collected into a Corvac ${ }^{\circledR}$ integrated serum separator tube (Sherwood Medical, UK) for determining serum levels of glucose, triglycerides, cholesterol, and uric acid. The remaining $5 \mathrm{ml}$ was collected into EDTA-coated vacutainers ${ }^{\circledR}$ (Becton-Dickinson, UK) for the measurement of MDA in plasma and for analysis of glycated haemoglobin $\left(\mathrm{HbA}_{1 \mathrm{c}}\right)$. One of the $5 \mathrm{ml}$ lithium heparin collected blood was centrifuged at $700 \mathrm{~g}$ for $10 \mathrm{~min}$. $250 \mu \mathrm{l}$ (in duplicate) of the resultant plasma fraction (for vitamin C analysis) was mixed with $500 \mu \mathrm{l}$ of a $10 \%$ metaphosphoric acid solution (w/v distilled $\mathrm{H}_{2} \mathrm{O}$; Sigma, Poole, UK). The remaining plasma was pipetted into labelled eppendorfs ( $250 \mu \mathrm{l}$ per eppendorf) and stored at $-70^{\circ} \mathrm{C}$ until required. The red cell concentrate (RCC) was washed three times with $5 \mathrm{ml}$ of cold phosphate buffered saline (Sigma, Poole, UK) and centrifuged at $700 \mathrm{~g}$ for $10 \mathrm{~min}$. The resultant washed RCC was pipetted into labelled eppendorfs $(250 \mu \mathrm{l}$ per eppendorf) and stored at $-70^{\circ} \mathrm{C}$ until required. The EDTA blood was centrifuged at $700 \times g$ for 10 min then $80 \mu \mathrm{l}$ (in duplicate) of the resulting plasma was pipetted into labelled eppendorfs and stored at $-70^{\circ} \mathrm{C}$ for MDA analysis. The remaining blood was re-suspended and stored at $4^{\circ} \mathrm{C}$ for $\mathrm{HbA}_{1 \mathrm{c}}$ analysis. The Corvac ${ }^{\circledR}$ serum sample was stored at $4^{\circ} \mathrm{C}$ until transported, together with the remaining EDTA blood, to The Biochemistry Laboratory, Altnagelvin Hospital. Mononuclear cells were isolated from the second $5 \mathrm{ml}$ lithium heparin blood using the method described by Böyum [19]. Following the removal of the mononuclear layer the blood sample was further processed for the separation of neutrophils using a dextran sedimentation method described by Markert et al., [20]. The resulting neutrophil pellet was re-suspended in $5 \mathrm{ml}$ PBS and kept at $4^{\circ} \mathrm{C}$ in the dark, for use the same day in the comet assay. Cell viability was assessed by trypan blue exclusion following isolation, and was found to be $>95 \%$.

\section{Assessment of Biochemical Analytes}

The following assays were carried out within The Biochemistry Laboratory, Altnagelvin Hospital. Analysis of the serum levels of cholesterol, triglycerides and glucose were carried out using the Beckman Synchron $\mathrm{CX}{ }^{\circledR}$ Systems automated system (for in vitro diagnostic use) and commercially available kits, based on the methods described by Allain et al., [21] Tietz [22] and Public Health Service Centres for Disease Control [23] respectively. \% $\mathrm{HbA}_{1 \mathrm{c}}$ was determined by HPLC using the method described by John et al., [24].

\section{Assessment of In Vivo Antioxidant Status}

To assess in vivo antioxidant status the following analytes were quantified: plasma levels of vitamin C, measured on a Cobas $B{ }^{\circledR}$ autoanalyser using the method described by Vuilleumier and Keck [25] plasma levels of vitamin A and E were assayed by HPLC using the method described by Thurnham et al., [26] RCC activities of catalase (CAT), glutathione peroxidase (GPX) and superoxide dismutase (SOD) were determined on the Cobas Fara ${ }^{\circledR}$ using commercial kits (Randox Laboratories, Antrim, UK) based on the methods described by Aebi [27] Paglia et al., [28] and Jones and Suttle [29] respectively; serum levels of uric acid (UA) were determined using the Beckman 
Synchron $\mathrm{CX}{ }^{\circledR}$ Systems automated system (for in vitro diagnostic use) based on the method described by Fossati et al., [30].

\section{The Alkaline Comet Assay}

The alkaline comet assay facilitates the detection of DNA strand-breakage, alkali-labile abasic sites, and intermediates in base- or nucleotide-excision repair. The alkaline comet assay procedure in this study was a modification of the method described by Singh et al., [31] and has been described in detail by McKelvey Martin et al., [32].

\section{Image Analysis of Slides}

Slides were stored in a light-proof box containing tissues moist with PBS and viewed within 12 hours of staining. Observations were made using an Ophtiphot II compound microscope (Nikon) equipped with an epifluorescence mercury lamp source (excitation filter 515, barrier filter $590 \mathrm{~nm}$ ) and x 40 Nikon Fluor objective (numerical aperture 0.85 ), and Komet 3.0 image analysis programme (Kinetic Imaging Ltd, Liverpool, UK).

\section{Analysis of DNA Damage}

The image analysis software provides a full range of densitometric and geometric parameters describing the complete comet, as well as the head and tail portions. Since the comet assay essentially reflects the displacement of fluorescence from the head to the tail in damaged cells we used \%tail DNA i.e. the percentage of total nuclear DNA that has migrated to the tail, as the parameter to quantify basal levels of DNA damage. Each blood/blood cell type sample was analysed in duplicate and 50 cells per slide were counted.

\section{Quantification of Plasma Levels of the Lipid Peroxidation Product, Malondialdehyde (MDA)}

In this study the method described by Young and Trimble [33] was used to quantify plasma levels of the lipid peroxidation product, MDA. In this method MDA, produced by the hydrolysis of lipid hydroperoxides heated under acid conditions, reacts with 2thiobarbituric acid (TBA) to form a MDA-TBA (1:2) complex with an absorbance maximum at $532 \mathrm{~nm}$.

The HPLC system used included a Spectra series AS100 (Thermo Separation Products) sample injector with a $50 \mu$ l sample loop, a Spectra-Physics SP4290 integrator and SP8800 HPLC pump, a Perkin Elmer LC240 fluorescence detector. The detector was set at excitation $523 \mathrm{~nm}$ and emission $553 \mathrm{~nm}$. A Supelco LC-18 column was used for separation of the MDATBA adduct. The mobile phase was a $50 \%$ HPLC grade methanol (BDH Laboratory Supplies, UK) and $50 \% 25 \mathrm{mM}$ phosphate buffer $\left(70 \% \mathrm{KH}_{2} \mathrm{PO}_{4}: 30 \%\right.$ $\mathrm{Na}_{2} \mathrm{HPO}_{4}$ ) at pH 6.5, with a flow rate of $0.8 \mathrm{ml} / \mathrm{min}$. The data was collected on a PC with the package, WINner On Windows. The yield of MDA from 1,1,3,3tetramethoxypropane was calculated using the molar coefficient of the MDA-TBA adduct at $532 \mathrm{~nm}(1.56 \mathrm{x}$ $10^{5} \mathrm{l} / \mathrm{cm} / \mathrm{mol}$ ) as described by Yu et al., [34].

\section{Statistical Analysis}

Statistical analysis was performed using the SPSS statistical package to compare the variances of all parameters examined using Levene's test of homogeneity of variances. Differences in measured parameters between normal and type I participants were assessed by the Mann-Whitney $U$ test, since the variances in the two samples were heterogeneous. Differences in the measured parameters between type I participants with, and without, complications were measured using the Student's t-test. The relationship between DNA damage and $\% \mathrm{HbA}_{1 c}$ was analysed using least squares. All results are expressed as mean \pm standard error of the mean (SEM). A p value of $<0.05$ was considered statistically significant. No significant sex- or age-related differences in the biochemical parameters measured were observed so male and female data are presented together in one group.

\section{RESULTS}

$\% \mathrm{HbA}_{1 \mathrm{c}}$ was significantly elevated in the plasma of the Type 1 participants, $(7.71 \pm 0.21 ; n=50)$ compared to controls $(4.28 \pm 0.06 ; n=50 ; p<0.01)$, (Table 1). The range of levels indicated that all Type I participants were under acceptable clinical control. The Type 1 participants were also tested routinely for the presence of ketone bodies in urine and for of microalbuminuria when they attended the diabetic clinic. There was no evidence for ketosis or microalbuminuria in any of the Type 1 participants admitted to the study. The good glycaemic control is also reflected by serum levels of cholesterol and of triglycerides, which revealed no significant differences in those Type 1 participants without complications, compared to controls. However, serum cholesterol levels in the Type 1 participants with complications were significantly elevated when compared to controls. 
Table 1: Participant Group Profile

\begin{tabular}{|c|c|c|c|c|}
\hline Participants & $\begin{array}{l}\text { Controls } \\
n=50\end{array}$ & $\begin{array}{c}\text { Type I DM } \\
\text { whole group } \\
n=50\end{array}$ & $\begin{array}{c}\text { Type I DM } \\
\text { without complications } \\
n=\mathbf{3 8}\end{array}$ & $\begin{array}{c}\text { Type I DM } \\
\text { with complications } \\
n=12\end{array}$ \\
\hline Age (years) & $37.6 \pm 1.49$ & $36.4 \pm 1.96$ & $32.2 \pm 1.57$ & $44.3 \pm 5.78$ \\
\hline Gender & $22 \mathrm{~F}: 28 \mathrm{M}$ & $20 \mathrm{~F}: 30 \mathrm{M}$ & $14 \mathrm{~F}: 24 \mathrm{M}$ & $6 \mathrm{~F}: 6 \mathrm{M}$ \\
\hline Smoker & none & 8 & 6 & 2 \\
\hline Duration of IDDM & - & $16.3 \pm 1.52$ & $13.4 \pm 1.35$ & $20.0 \pm 3.42$ \\
\hline$\% \mathrm{HbA}_{1 \mathrm{c}}$ & $4.28 \pm 0.06$ & $\star * \star 7.71 \pm 0.21$ & $* * * 7.59 \pm 0.24$ & $* * * 8.12 \pm 0.35$ \\
\hline Cholesterol (mmol/l) & $4.74 \pm 0.12$ & $4.90 \pm 0.15$ & $4.62 \pm 0.16$ & ††5.66 \pm 0.34 \\
\hline Triglycerides (mmol/l) & $1.19 \pm 0.19$ & $1.40 \pm 0.16$ & $1.34 \pm 0.19$ & $1.48 \pm 0.30$ \\
\hline
\end{tabular}

Values are presented as mean \pm SEM in all groups. ${ }^{* * *} p<0.01$ and $\dagger+p<0.05$, when compared to controls. $F$ denotes female; $M$ denotes male.

Of the 50 Type 1 participants, eight were smokers; three of the smokers also had at least one complication. Because of small numbers it was not possible to determine by statistical analysis if the values obtained for the various endpoints $\left(\% \mathrm{HbA}_{1 \mathrm{c}}\right.$ and neutrophil DNA damage) were different in Type 1 participants who smoked compared to those who did not. However, when the smokers were removed from the analysis the results were no differences in any of the parameters analysed.

The results of this study revealed differences in the activities/levels of a number of the antioxidants measured, when compared to controls (Table 2). GPx activity, SOD activity, UA concentration, and vitamin C concentration were all significantly reduced in Type 1 participants, compared to controls. CAT activity in RCC was significantly elevated in Type 1 participants compared to controls (Table 2). There were no significant differences in the plasma levels of the vitamins $A$ and $E$ in Type 1 participants when compared to controls (Table 2). No significant difference in the mean plasma vitamin $\mathrm{C}$ concentration in Type 1 group without complications, compared to controls, was observed. Conversely, mean plasma vitamin $\mathrm{C}$ concentration in the Type 1 group with complications was significantly reduced, compared to controls. For all other antioxidants measured there were no detectable differences in the activities/levels in the Type 1 group with complications, compared to those without complications.

The Type 1 participants had significantly elevated levels of MDA when compared to controls (Table 2). However, when participants with complications were excluded from the analysis the significance was lost. On the other hand, there were markedly increased MDA concentrations in samples from Type 1 participants with complications compared to controls. There was no significant correlation between MDA levels and $\% \mathrm{HbA}_{1 \mathrm{c}}$ for any of the Type 1 groups.

We observed significantly elevated basal levels of DNA damage in the neutrophil fraction of Type 1 participants, when compared to control participants $(8.40 \pm 0.85$ and $4.33 \pm 0.27$ respectively, $p<0.0001$, Table 2). This significant elevation in basal levels of neutrophil DNA damage was observed in participants both with and without complications. However, there was no significant difference in levels of neutrophil DNA damage measured in the Type 1 participants with complications compared to those who did not have complications.

There was no correlation between neutrophil DNA damage levels (\%tail DNA) and $\% \mathrm{HbA}_{1 \mathrm{c}}$ in the Type 1 participants.

\section{DISCUSSION}

In the present study significant alterations in the activities/levels of certain antioxidants in Type 1 participants, compared to controls were observed. There have been conflicting reports on antioxidant status in Type 1, with reports indicating increased levels, $[4,5,14,34]$ decreased levels, $[4,8,14,35]$ and no change $[4,8]$ depending on the antioxidant investigated. It has been suggested that the low levels of antioxidant enzymes indicate increased free radical activity, and therefore increased oxidative stress in diabetes. [36] In addition, it has been reported that in conditions of slight oxidative stress, the antioxidant enzymes SOD, GPx and CAT may be inducible [37] as a result of increased levels of their respective substrates, $\mathrm{O} 2$.- and $\mathrm{H}_{2} \mathrm{O}_{2}$. Specifically, we found significantly reduced activities in SOD, GPx and levels 
Table 2: Neutrophil DNA Damage, Plasma Malondialdehyde Levels and In Vivo Antioxidant Status in Type 1 DM and Control Participants

\begin{tabular}{|c|c|c|c|c|}
\hline Parameters & $\begin{array}{l}\text { Controls } \\
(n=50)\end{array}$ & $\begin{array}{c}\text { Type I DM } \\
\text { whole group } \\
\quad(n=50)\end{array}$ & $\begin{array}{l}\text { Type I DM without } \\
\text { complications } \\
(n=38)\end{array}$ & $\begin{array}{l}\text { Type I DM with } \\
\text { complications } \\
\quad(n=12)\end{array}$ \\
\hline DNA damage (\%tail DNA) & $4.32 \pm 0.27$ & $* * * 8.40 \pm 0.85$ & $* * * 8.44 \pm 1.05$ & $* \star * 7.58 \pm 0.92$ \\
\hline Plasma MDA $(\mu \mathrm{mol} / \mathrm{l})$ & $0.40 \pm 0.02$ & $\dagger 0.47 \pm 0.03$ & $0.45 \pm 0.03$ & ${ }^{*} 0.55 \pm 0.07$ \\
\hline Superoxide dismutase $(\mathrm{U} / \mathrm{gHb})$ & $1339.88 \pm 10.02$ & $* * * 1158.15 \pm 40.03$ & $* * * 1164.46 \pm 43.99$ & **1138.16 \pm 95.28 \\
\hline Glutathione peroxidase $(\mathrm{U} / \mathrm{gHb})$ & $44.28 \pm 1.54$ & $\dagger 39.35 \pm 1.64$ & $39.80 \pm 1.87$ & $37.92 \pm 3.50$ \\
\hline Catalase (k/gHb) & $40.45 \pm 2.03$ & $* * * 58.57 \pm 2.67$ & $* * * 56.96 \pm 3.31$ & ${ }^{* * *} 63.66 \pm 4.71$ \\
\hline Vitamin A $(\mu \mathrm{mol} / \mathrm{l})$ & $2.53 \pm 0.08$ & $2.58 \pm 0.17$ & $2.41 \pm 0.13$ & $3.13 \pm 0.54$ \\
\hline Vitamin $E(\mu \mathrm{mol} / \mathrm{l})$ & $32.13 \pm 1.53$ & $36.01 \pm 1.63$ & $35.58 \pm 1.85$ & $37.38 \pm 3.59$ \\
\hline Vitamin $C(\mu \mathrm{mol} / \mathrm{l})$ & $23.2 \pm 1.81$ & $\dagger 17.3 \pm 1.63$ & $18.84 \pm 1.80$ & $\dagger 13.9 \pm 3.65$ \\
\hline Uric acid $(\mu \mathrm{mol} / \mathrm{l})$ & $276.7 \pm 11.60$ & $\dagger 235.5 \pm 9.40$ & *235.9 \pm 9.92 & $227.0 \pm 21.97$ \\
\hline
\end{tabular}

Values are presented as mean \pm SEM in all groups. ${ }^{* * *} p<0.0001 ;{ }^{* *} p<0.001 ;{ }^{*} p<0.01$; and $\dagger p<0.05$, when compared to controls.

of UA and vitamin C, and a significant elevation in CAT activity, in the Type 1 participants, compared to controls. The general consensus is that plasma and tissue levels of vitamin $C$ are reduced in diabetes [3941] our results are in agreement with this consensus. $\mathrm{UA}$, or more correctly urate (at physiological pH values) has been shown to be a selective antioxidant, it also prevents oxidative inactivation of endothelial enzymes (cyclooxygenase, angiotensin converting enzyme) and preserves the ability of the endothelium to mediate vascular dilatation in the face of oxidative stress [41]. The significant reduction in UA which is found in this study in the Type 1 participants, could render the endothelium more susceptible to ROS-mediated oxidative damage, which may be a contributing factor in the development of vascular complications and/or the propagation of peroxidation products in Type 1 participants. This study did not find any significant changes in plasma levels of vitamins $A$ or $E$.

Levels of the lipid peroxidation product, MDA, were significantly elevated in this study only in the plasma of the Type 1 participants with complications, despite the relatively good metabolic control of these participants. There was no significant difference in MDA levels in the Type 1 participants without complications, compared to controls. It has been reported that good metabolic control delays the onset and slows the progression of diabetic retinopathy, nephropathy and neuropathy in Type 1 participants [43]. Yet investigations into antioxidant status and lipid peroxidation products in Type 1 participants have for the most part been in poorly controlled, or in Type 1 participants with complications [4,7-10]. There is little information available to determine the percentage of Type 1 participants with good control. Recently the focus has been on type 2 diabetes and only a few groups have reported on levels of lipid peroxidation, antioxidant status, and free radical generation in Type 1 diabetes $[1,2,8,12$, $]$. While we did not observe an increase in MDA in the Type 1 group without complications, which agrees with Ruiz et al., [8] findings, we did observe elevated levels in the Type 1 group with complications. Similarly Sato et al., [9] reported elevated levels of MDA in Type 1 participants with angiopathy (either macro- or micro-vascular disease), and Gallou et al., [46] reported higher MDA levels in both Type 1 and Type 2 diabetes, with markedly elevated MDA levels in those participants with vascular complications, compared to those without complications. Rimm [47] reported a strong correlation between vitamin $\mathrm{E}$ status and the development of vascular complications. In our study Type 1 participants had slightly elevated levels of vitamin E compared to controls, which may have a protective role by breaking the autocatalytic cycle and therefore reduce and/or help to prevent the development of angiopathy, by preventing the excessive formation of lipid peroxidation products.

There were no significant differences in triglycerides or cholesterol levels in the Type 1 group without complications, when compared to controls. However, there was an elevated level of serum cholesterol in the Type 1 group with complications, when compared to controls. The metabolism of cholesterol in diabetes is a very complex process, however, elevated levels of serum cholesterol are associated with the development of atherosclerosis in both non-diabetic and Type 1 
participants, indeed, even Type 1 participants with a similar lipid profile to non-diabetic counterparts are much more at risk of developing atherosclerosis [47].

In the present study we used the alkaline comet assay to measure basal levels of DNA damage in freshly isolated neutrophils from Type I participants. We found significantly increased levels of DNA damage (\%tail DNA) in the Type 1 group compared to the control group (Table 2). We reported similar findings previously [48], when we also measured whole blood, mononuclear and lymphocyte DNA damage in 23 participants with type I diabetes and 32 age- and sexmatched controls and reported elevated, but not significant, levels of DNA damage in whole blood and white cell fractions. In the current study we had 50 participants in the Type 1 group and 50 control participants. We sub-divided the Type 1 group into those with and those without complications and were surprised to find no significant difference in levels of DNA damage in participants with complications compared to those without complications (Table 2). There have been conflicting reports of levels of DNA damage in mononuclear cells from diabetic participants reported in the literature. Collins et al. [49] reported elevated levels of DNA damage in mononuclear cells from Type I participants with poor glycaemic control $\left(11.0 \pm 2.9 \% \mathrm{HbA}_{1 \mathrm{c}}\right)$. Lorenzi et al., [50] measured DNA damage, using the alkali unwinding assay, in mononuclear cells from patients with poor glycaemic control $\left(12.9 \pm 2.4 \% \mathrm{HbA}_{1 \mathrm{c}}\right)$ and found elevated levels of DNA damage. In the same study they also reported no significant changes in DNA damage in participants with good glycaemic control $\left(\% \mathrm{HbA}_{1 c} 7.4 \pm 1.5 \%\right)$, while others report elevated levels of oxidative DNA damage in lymphocytes [51] in well controlled participants. In the current study and in previous work we measured levels of DNA damage in lymphocytes using an ELISA [14], and the Comet assay [48] we found significantly higher levels of DNA damage in lymphocyte and neutrophil fractions, in the Type 1 participants compared to controls even with good glycaemic control.

This study found elevated levels of DNA damage in the neutrophil fraction both with and without complications and in participants with relatively good gylcaemic control. Under normal circumstances stimulated neutrophils kill bacteria via the production of ROS (superoxide anion, hydroxyl radicals and hydrogen peroxide) during the 'respiratory burst' [52]. Reports indicate that diabetic participants' neutrophils are in a chronic state of activation generating increased levels of ROS [6]. It is well documented that ROS are capable of causing DNA damage [13] and it has been shown that neutrophils in a chronic low state of activation are capable of generating sufficient ROS to induce DNA damage in vitro [53]. Under normal circumstances activated neutrophils are protected from ROS-induced damage by increasing their intake of vitamin $\mathrm{C}$ by as much as ten-fold above the concentrations present in normal neutrophils. However, Type 1 participant's plasma, as we report here, and leucocyte levels of vitamin $C$ have been shown to be significantly reduced $[14,39-41]$. This is likely to contribute to the elevated levels of DNA damage reported here. In addition reports indicate that neutrophil production of hypochlorous acid and $\mathrm{N}$ chloramines inhibit DNA repair [54]. Such inhibition of repair in vivo may well exacerbate levels of ROSinduced damage to DNA in neutrophils within diabetic participants regardless of the absence or presence of complications.

Overall then, we observed an imbalance in the levels of antioxidant defences, even in the Type 1 group without complications, which may be the result of an increase in oxidative stress. The increased oxidative stress alone in these participants did not result in increased peroxidation of plasma lipids. However, following the development of (macro- and/or micro-) angiopathy (complications), leakage of peroxidised lipids back into the plasma may take place, initiating a vicious cycle of further damage, regardless of the glycaemic control of the participants with Type 1. This would suggest that factors other than glycaemic control need to be addressed in order to improve the prognosis for participants with Type 1. Our data suggests that even with acceptable glycaemic control participants with Type 1 have a significantly elevated level of neutrophil DNA damage in vivo. This may contribute to the altered neutrophil function, reported elsewhere, in patients with Type 1 and is worthy of further investigation as it would appear that this process is not governed by glycaemic control nor the development of diabetic complications.

\section{REFERENCES}

[1] Kaneto H, Katakami N, Kawamori D, Miyatsuka T, Sakamoto $\mathrm{K}$, Matsuoka TA, Matsuhisa M, Yamasaki Y. Involvement of oxidative stress in the pathogenesis of diabetes. Antioxid Redox Signal 2007; 9(3): 355-66. http://dx.doi.org/10.1089/ars.2006.1465

[2] Giacco F, Brownlee M. Oxidative stress and diabetic complications Circ Res 2010; 107(9): 1058-70.

http://dx.doi.org/10.1161/CIRCRESAHA.110.223545 
[3] Rosen P, Nawroth PP, King G, Moller W, Tritschler HJ, Packer $L$. The role of oxidative stress in the onset and progression of diabetes and its complications: A summary of a Congress Series sponsored by UNESCO MCBN, the American Diabetes Association and the German Diabetes Society. Diabetes Metab Res Rev 2001; 17: 189-912. http://dx.doi.org/10.1002/dmrr.196

[4] VanderJagt DJ, Harrison JM, Ratliff DM, Hunsaker LA, Vander Jagt DL. Oxidative stress indices in IDDM subjects with and without long-term diabetic complications. Clin Biochem 2001; 34(4): 265-70.

http://dx.doi.org/10.1016/S0009-9120(01)00204-1

[5] Maxwell SR, Thomason H, Sandler D, Leguen C, Baxter MA, Thorpe GH, Jones AF, Barnett, AH. Antioxidant status in patients with uncomplicated insulin-dependent and noninsulin-dependent diabetes mellitus. Eur J Clin Invest 1997; 27(6): 484-490.

http://dx.doi.org/10.1046/j.1365-2362.1997.1390687.x

[6] Wierusz-Wysocka B, Wykretowicz A, Byks H, Sadurska K, Wysocki $H$. Polymorphonuclear neutrophils adherence, superoxide anion $\left(\mathrm{O}_{2}{ }^{-}\right)$production and $\mathrm{HB}_{\mathrm{A} 1}$ level in diabetic patients. Diabetes Res Clin Prac 1993; 21: 109-114. http://dx.doi.org/10.1016/0168-8227(93)90057-C

[7] Zozulinska DA, Wierusz-Wysocka B, Wysocki H, Majchrzak $A E$, Wykretowicz $A$. The influence of insulin-dependent diabetes mellitus (IDDM) duration on superoxide anion and hydrogen peroxide production by polymorphonuclear neutrophils. Diabetes Res Clin Prac 1996; 33: 139-144. http://dx.doi.org/10.1016/0168-8227(96)01289-2

[8] Ruiz C, Alegría A, Barberá R, Farré R, Lagarda MJ. Lipid peroxidation and antioxidant enzyme activities in patients with type 1 diabetes mellitus. Scand J Clin Lab Invest 1999, 59(2): 99-105.

http://dx.doi.org/10.1080/00365519950185823

[9] Sato Y, Hotta N, Sakamoto N, Matsuoka S, Ohishi N, Yagi, K. Lipid peroxide levels in plasma of diabetic patients. Biochem Med 1979; 21: 104-107. http://dx.doi.org/10.1016/0006-2944(79)90061-9

[10] Matough FA, Budin SB, Hamid ZA, Alwahaibi N, Mohamed J. The role of oxidative stress and antioxidants in diabetic complications. Sultan Qaboos Univ Med J 2012; 12(1): 5-18.

[11] Biasi F, Vizio B, Mascia C, Gaia E, Zarkovic N, Chiarpotto E, Leonarduzzi G, Poli G. c-Jun N-terminal kinase upregulation as a key event in the proapoptotic interaction between transforming growth factor-beta1 and 4-hydroxynonenal in colon mucosa. Free Radic Biol Med 2006; 41(3): 443-54. http://dx.doi.org/10.1016/j.freeradbiomed.2006.04.005

[12] Minko IG, Kozekov ID, Harris TM, Rizzo CJ, Lloyd RS, Stone MP Review Chemistry and biology of DNA containing 1,N(2)deoxyguanosine adducts of the alpha,beta-unsaturated aldehydes acrolein, crotonaldehyde, and 4-hydroxynonenal. Chem Res Toxicol 2009; 22(5): 759-78.

http://dx.doi.org/10.1021/tx9000489

[13] Jaganjac M1, Cacev T, Cipak A, Kapitanović S, Gall Troselj K, Zarković N. Even stressed cells are individuals: second messengers of free radicals in pathophysiology of cancer. Croat Med J 2012; 53(4): 304-9.

http://dx.doi.org/10.3325/cmj.2012.53.304

[14] Hannon-Fletcher MPA, Hughes C, Moles KW, Barnett CR, Barnett YA. An investigation of in vivo antioxidant status and DNA damage in patients with IDDM. In Basu TK, Temple NJ, Garg ML editors. Antioxidants in Human Health: Oxford: CABI Publishing, 1999; p259-269.

[15] Dandona P, Thusu K, Cook S, Snyder B, Makowski J, Armstrong D, Nicotera T. Oxidative damage to DNA in diabetes mellitus. Lancet 1996; 347: 444-445. http://dx.doi.org/10.1016/S0140-6736(96)90013-6

[16] Collins AR, Raslová K, Somorovská M, Petrovská H, Ondrusová A, Vohnout B, Fábry R, Dusinská M. DNA damage in diabetes: correlation with a clinical marker. Free Radic Biol Med 1998; 25(3): 373-7.

http://dx.doi.org/10.1016/S0891-5849(98)00053-7

[17] Lorenzi M, Montisano DF, Toledo S, Wong HC. Increased single strand breaks in DNA of lymphocytes from diabetic subjects. J Clin Invest 1897; 79: 653-656.

http://dx.doi.org/10.1172/JCl112863

[18] Anderson D, Yu TW, Wright J, loannides C. An examination of DNA strand breakage in the Comet Assay and antioxidant capacity in diabetic patients. Mutation Res 1998; 398: 151161.

http://dx.doi.org/10.1016/S0027-5107(97)00271-6

[19] Böyum A. Isolation of mononuclear cells and granulocytes from human blood, in: Norwegian Defence Research establishment Division for Toxicology Kjeller Norway. 1980, Paper iv: pp. 77-89.

[20] Markert M, Particia CA, Babior BM. Measurement of O2production by human neutrophils. The preparation and assay of NADPH oxidised containing particles from human neutrophils, Method. Enzymol 1984; 105: 358-362. http://dx.doi.org/10.1016/S0076-6879(84)05048-5

[21] Allain CC, Poon LS, Chan CS, Richmond W, Fu PC. Enzymatic determination of total serum cholesterol. Clin Chem 1974; 20(4): 470-475.

[22] Tietz NW. Specimen collection and processing; sources of biological variation. In Saunders W, editors. Textbook of Clinical Chemistry, 2nd ed. Philadelphia: 1994.

[23] Public Health Service Centers for Disease Control. A proposed method for determining glucose using hexokinase and glucose-6-phosphatase dehydrogenase. In Public Health Service, Centers for Disease Control 1976.

[24] John WG, Bullock DG, MacKenzie F. Methods for the analysis of glycated haemoglobins: what is being measured? Diabetic Med 1992; 9: 15-19.

http://dx.doi.org/10.1111/j.1464-5491.1992.tb01708.x

[25] Vuilleumier JP, Keck E. Flurometric assay of vitamin C in biological materials using a centrifugal analyser with fluorescence attachment. J Micronutr Anal 1989; 5: 25-34.

[26] Thurnham DI, Smith E, Flora PS. Concurrent liquidchromatographic assay of retinol, $\alpha$-tocopherol, $\beta$-carotene, $\alpha$-carotene, lycopene, and $\beta$-cryptoxanthin in plasma, with tocopherol acetate as internal standard. Clin Chem 1988; 30(2): 377-381.

[27] Aebi HE. Catalase. Methods in Enzymatic Analysis 1974; 2 : 121-126.

[28] Paglia DE, Valentine WN. Studies on the quantitative and qualitative characterization of erythrocyte glutathione peroxidase. J Lab Clin Med 1967; 70(1): 158-169.

[29] Jones DG, Suttle NF. Some effects of copper deficiency on leucocyte function in sheep and cattle. Res Vet Sci 1981; 31: 151-156.

[30] Fossati P, Prencipe L, Berti G. Use of 3,5-dichloro-2hydroxybenzenesulfonic acid, 4-aminophenazone chromogenic system in direct enzymic assay of uric acid in serum and urine. Clin Chem 1980; 22(2): 227-231.

[31] Singh NP, McCoy MT, Trice RR, Schneider EL. A simple technique for quantification of low levels of DNA damage in individual cells. Exp Cell Res 1988; 175: 184-194. http://dx.doi.org/10.1016/0014-4827(88)90265-0

[32] McKelvey-Martin VJ, Ho ET, McKeown SR, Johnston SR, McCarthy PJ, Rajab NF, Downes CS. Emerging applications of the single cell gel electrophoresis (Comet) assay. I. Management of invasive transitional cell human bladder carcinoma. II. Fluorescent in situ hybridization Comets for the identification of damaged and repaired DNA sequences in individual cells. Mutagenesis 1998; 13(1): 1-8. http://dx.doi.org/10.1093/mutage/13.1.1 
[33] Young IS, Trimble ER. Measurement of malondialdehyde in plasma by high performance liquid chromatography with fluorimetric detection. Ann Clin Biochem 1991; 28: 504-508. http://dx.doi.org/10.1177/000456329102800514

[34] Kawamura N, Ookawara T, Suzuki K, Konoshi K, Mino M, Taniguchi N. Increased glycated Cu,Zn-superoxide dismutase levels in erythrocytes of patients with insulindependent diabetes mellitus. J Clin Endocrin Metab 1992; 74(6): 1352-1354.

[35] Olczyk K, Koscielniak-Kocurek E, Sonecki P, Zdenkowski W. The lipid peroxidation products and the enzymes of antioxidant system in patients with diabetes mellitus. Rocz Akad Med Bialymstoku 1994; 39: 93-99.

[36] Wolff SP. Diabetes mellitus and free radicals: free radicals, transition metals and oxidative stress in the aetiology of diabetes mellitus and complications. Br Med Bull 1993; 49: 642.

[37] Hägglöf B, Marklund SL, Holmgreen G. CuZn superoxide dismutase, $\mathrm{Mn}$ superoxide dismutase, catalase and glutathione peroxidase in lymphocytes and erythrocytes in insulin-dependent diabetic children. Acta Endocrinol 1983; 102: 235-239.

[38] Mann GV. Hypothesis: the role of vitamin C in diabetic angiopathy. Perspect Biol Med 1974; 210-217.

[39] Cunningham JJ. Altered vitamin $C$ transport in diabetes mellitus. Med Hypotheses 1988; 26: 263-265. http://dx.doi.org/10.1016/0306-9877(88)90131-4

[40] Cunningham JJ, Ellis SL, McVeigh KL, Levine RE, CallesEscandon J. Reduced mononuclear leukocyte ascorbic acid content in adults with insulin-dependent diabetes mellitus consuming adequate dietary vitamin C. Metabolism 1991; 40(2): 146-149. http://dx.doi.org/10.1016/0026-0495(91)90165-S

[41] Bode AM, Yavarow CR, Fry DA, Vargas T. Enzymatic basis for altered ascorbic acid and dehydroascorbic acid levels in diabetes. Biochem Biophys Res Commun 1993; 191(3): 1347-1353. http://dx.doi.org/10.1006/bbrc.1993.1365

[42] Stankova L, Riddle M, Larned J, Burry K, Menashe D, Hart J, Bigley R. Plasma ascorbate concentrations and blood cell dehydroascorbate transport in patients with diabetes melltus. Metabolism 1984; 33(4): 347-353. http://dx.doi.org/10.1016/0026-0495(84)90197-5

[43] The Diabetes Control and Complications Trial Research Group. The effect of intensive treatment of diabetes on the development and progression of long-term complications in insulin-dependent diabetes mellitus. N Engl J Med 1993; 329(14): 977-986. http://dx.doi.org/10.1056/NEJM199309303291401
[44] Ceriello A, Giugliano D, Quatraro A, Donzella C, Dipalo G, Lefebvre PJ. Vitamin E reduction of protein glycosylation in diabetes. Diabetes Care 1991; 14(1): 68-72. http://dx.doi.org/10.2337/diacare.14.1.68

[45] Nishigaki I, Hagihara M, Tsunekawa H, Maseki M, Yagi K. Lipid peroxide levels of serum lipoprotein fractions of diabetic patients. Biochem Med 1981; 25: 373-378. http://dx.doi.org/10.1016/0006-2944(81)90096-X

[46] Gallou G, Ruelland A, Legras B, Maugendre D, Allanic H, Cloarec L. Plasma malondialdehyde in type 1 and type 2 diabetic patients. Clinica Chim Acta 1993; 214: 227-234. http://dx.doi.org/10.1016/0009-8981(93)90114-J

[47] Rimm EB, Stampfer MJ, Ascherio A, Giovannucci E, Colditz GA, Willett WC. Vitamin $E$ consumption and the risk of coronary heart disease in men. N Engl J Med 1993; 322(20): 1450-1456.

http://dx.doi.org/10.1056/NEJM199305203282004

[48] Hannon-Fletcher MP, O'Kane MJ, Moles KW, Weatherup C, Barnett CR, Barnett YA. Levels of peripheral blood cell DNA damage in insulin dependent diabetes mellitus human subjects. Mutat Res 2000; 460(1): 53-60.

http://dx.doi.org/10.1016/S0921-8777(00)00013-6

[49] Collins AR1, Raslová K, Somorovská M, Petrovská $H$, Ondrusová A, Vohnout B, Fábry R, Dusinská M. DNA damage in diabetes: correlation with a clinical marker. Free Radic Biol Med 1998; 25(3): 373-7. http://dx.doi.org/10.1016/S0891-5849(98)00053-7

[50] Lorenzi M, Montisano DF, Toledo S, Wong HC. Increased single strand breaks in DNA of lymphocytes from diabetic subjects, J Clin Invest 1987; 79: 653-656. http://dx.doi.org/10.1172/JCl112863

[51] Dinçer $\mathrm{Y}$, Akçay T, Ilkova H, Alademir Z, Ozbay G. DNA damage and antioxidant defense in peripheral leukocytes of patients with Type I diabetes mellitus. Mutat Res 2003; 527(1-2): 49-55.

http://dx.doi.org/10.1016/S0027-5107(03)00073-3

[52] Esman V. The polymorphonuclear leucocyte in diabetes, Fresen J Anal Chem 1982; 311: 344-348.

http://dx.doi.org/10.1007/BF00481709

[53] Weitzman SA, Gordon LI. Inflammation and cancer: Role of phagocyte-generated oxidants in carcinogenesis. Blood 1990; 76: 655-663.

[54] Ogino T, Packer L, Maguire JJ. Neutrophil antioxidant capacity during the respiratory burst: loss of glutathione induced by chloramines. Free Radical Biol Med 1997; 23: 445-452. http://dx.doi.org/10.1016/S0891-5849(97)00115-9

(C) 2014 Hannon-Fletcher et al.; Licensee Lifescience Global.

This is an open access article licensed under the terms of the Creative Commons Attribution Non-Commercial License (http://creativecommons.org/licenses/by-nc/3.0/) which permits unrestricted, non-commercial use, distribution and reproduction in any medium, provided the work is properly cited. 